\title{
Observations of the grounding-line area at a floating glacier terminus
}

\author{
Ross D. Powell, Michael Dawber, James N. McInnes, \\ Department of Geology, Northern Illinois University, DeKalb, IL 60115, U.S.A. \\ Alex R. PyNe \\ Antarctic Research Centre, Victoria University of Wellington, Wellington, New Zealand
}

\begin{abstract}
A robotic submarine was used for the first observations of a grounding-line area of a floating glacier. The site was Mackay Glacier which terminates as a floating glacier tongue in the Ross Sea, at latitude $77^{\circ} \mathrm{S}$. Half of the $20 \mathrm{~m}$ thick basal debris layers in Mackay Glacier are deposited as subglacial till in the last $1.8 \mathrm{~km}$ that the glacier remains grounded. Subglacial till observed at and beyond the grounding line varies rapidly in texture and rheology spatially, occurring as a flat sheet, as flow-parallel flutes, or as bank forms into which it has been pushed at the grounding line. Very little free-flowing subglacial water was present during the observations, and no major subglacial water discharges appear to have occurred in the past. The other half of the basal debris is melted out up to $1.5 \mathrm{~km}$ in front of the grounding line, producing a sheet of glacimarine sediment as shelfstone diamicton and mud draped on subglacial till. Both till and glacimarine sediment may be turbated by icebergs. This simple model of till overlain by shelfstone diamicton and mud is a direct contrast to sedimentary depositional systems at tide-water termini of temperate glaciers.
\end{abstract}

\section{INTRODUCTION}

Processes at the grounding lines of floating marine termini of cold glaciers, such as ice shelves and floating tongues, are less well understood than those at grounded tidewater cliffs of temperate glaciers, because access to floating cold glacier termini is more difficult (Powell and Domack, 1995). Previous workers have suggested some aspects of sedimentation style at grounding lines of floating ice-sheet termini either by conceptual hypothetical models or by inference from seismic reflection records of the Ross Ice Shelf grounding line and of Quaternary sediment on modern continental shelves (Drewry and Cooper, 1981; Powell, 1984; Alley and others, 1989; Engelhardt and others, 1990; Hambrey and others, 1991; King and others, 1991; Anderson and Bartek, 1992).

Reported here are the first observations of processes at the grounding line of a cold glacier with a floating terminus. For the study we used a submersible remotely operated vehicle (ROV) through access holes in the sea ice at the tongue margin. The ROV has about $500 \mathrm{~m}$ of tether and is equipped with a variety of oceanographic instruments and sampling and operational sensors (Dawber and Powell, 1995).

The study site is Mackay Glacier, an outlet glacier from the East Antarctic Ice Sheet which flows through the Royal Society Range of the Transantarctic Mountains to end as a floating glacier tongue in Granite Harbour of the Ross Sea region at $77^{\circ} \mathrm{S}$ (Fig. 1). The Mackay is an intermediate type of Antarctic cold-ice glacier lying between the two cold-glacier end-members: thin glaciers with frozen beds ending as grounded tide-water cliffs and thick, fast flowing ice streams. On average the glacier is $5 \mathrm{~km}$ wide, and radio-echo sounding indicates thicknesses of more than $430 \mathrm{~m}$ (Calkin, 1974). The Mackay has a drainage basin area of about $10000 \mathrm{~km}^{2}$ with a centre flowline length of $165 \mathrm{~km}$, along which the surface velocity in the terminus region is $250 \mathrm{~m}_{\text {year }}{ }^{-1}$ (Macpherson, 1987).

As part of the Western geological party on Scott's 1910-13 Terra Nova expedition, Debenham (1923) carefully surveyed Granite Harbour in 1911-12, and his detailed plane-table maps show the Mackay Glacier Tongue (MGT) extending $10 \mathrm{~km}$ beyond Cuff Cape. However, the exact length of the tongue at that time is difficult to define since the position of the grounding line is uncertain. Currently, the MGT is up to $4 \mathrm{~km}$ long (Fig. 1).

Above sea level, the MGT is made of clean ice, free of all but minor aeolian debris. It ends in low ice cliffs that are commonly less than $10 \mathrm{~m}$ high. Around the terminus, large wedge-shaped chasms extending toward the interior of the MGT (Fig. 1) are formed by extensional deformation of the ice as it becomes laterally unconfined and spreads upon entering the sea. These chasms are sites at which large icebergs detach by fractures growing into the MGT from the chasm edge. ROV access holes were made deep in the chasms in order to examine as much interior ice of the glacier as possible. The MGT surface is melted quite rapidly by solar radiation during the summer months of late January and February when some small supraglacial streams discharge from the terminal cliffs. 


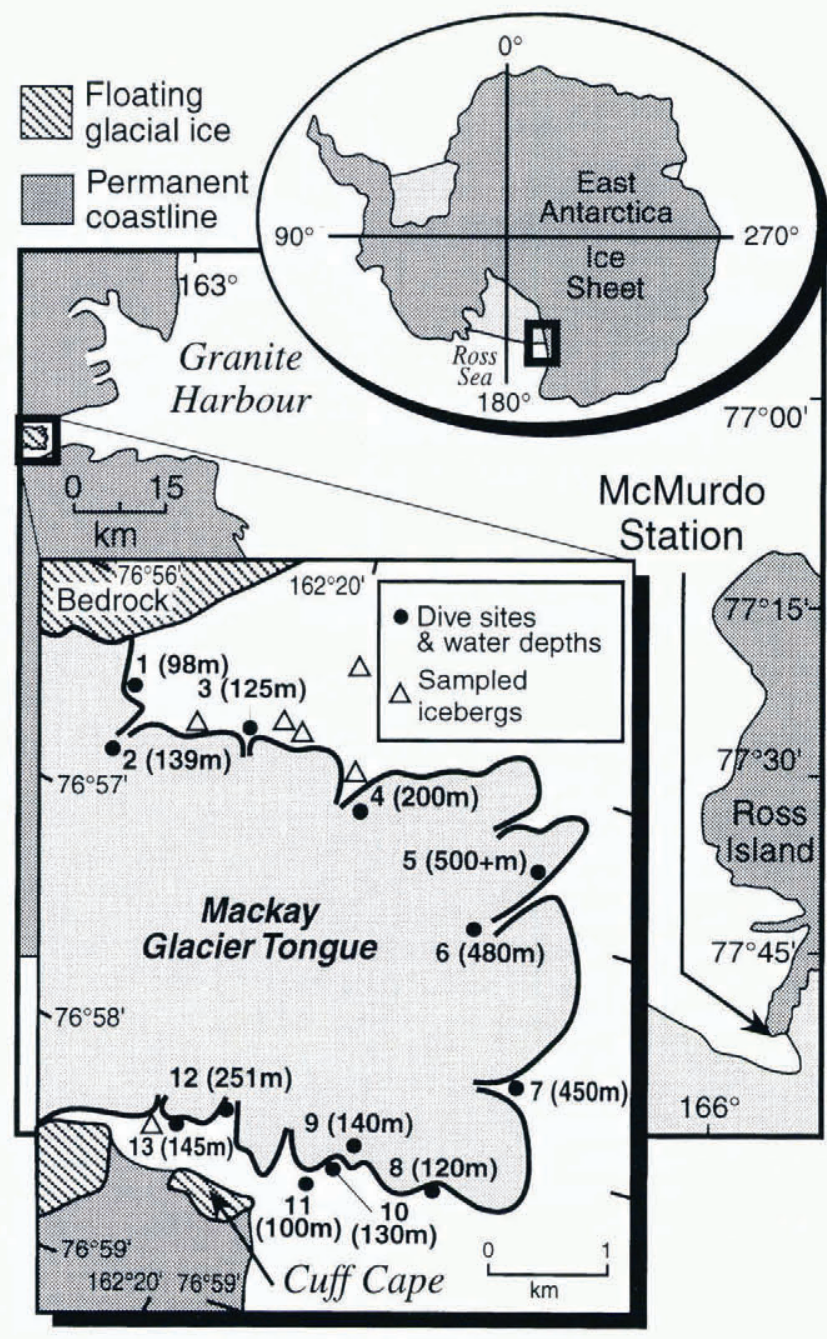

Fig. 1. ROV dive-site locations (numbers) with water depth directly at each hole and sampled icebergs (triangles) at the Mackay Glacier Tongue, located at Granite Harbour in McMurdo Sound, Ross Sea, Antarctica. The lerminus is shown in its 1994 position, and dive sites shown within the tongue were occupied in field seasons before 1994 when the terminus had a different geometry. Breaks in the terminus outline are large chasms. Dive site 8 is the pinning-point location.

\section{ROV OBSERVATIONS AND INTERPRETATION}

\section{Basal debris}

Using the ROV's depth sensor, basal debris at the grounding line was measured up to $20 \mathrm{~m}$ above the glacier sole in vertical faces of subglacial crevasses (Figs 2 and 3). These observations of basal debris are supplemented by descriptions made from icebergs calved from the sides of the MGT near its grounding line. The icebergs had remained virtually in place by being frozen-in by sea ice and had rotated such that an almost complete stratigraphy of the MGT was exposed up their sides.

Basal debris is brown and grey mud or diamicton in discontinuous debris-rich laminae or beds of dense bubblepoor ice between which ice is less dirty and more bubbly. Clasts range from angular to rounded. Some are faceted, and rare clasts of fine-grained rock types are striated. Angular, subglacially derived clasts several centimeters in diameter indicate that quarrying processes are active subglacially up-glacier where local melting and refreezing must occur. In order to prevent clasts from becoming edgerounded by abrasion against bedrock, layers of ice and debris at least as thick as the clast diameter must be frozenon almost immediately the clast is plucked, in order to remove it from the bed. Alternatively, a soft subglacial till may be present immediately down-glacier from the plucked bedrock, and a clast could plough through that without being rounded.

Composition of debris shows that most comes from Precambrian basement, but a few of the clasts are Beacon Supergroup sedimentary rock types originating from at least $90 \mathrm{~km}$ up-glacier where the last Beacon rocks are exposed in nunataks. The Precambrian rocks crop out along valley walls at the terminus, and extend at least 25$30 \mathrm{~km}$ inland from the present grounding line. However, the subglacial extent of Precambrian rocks is uncertain because, regionally, Beacon rocks rest unconformably above the Precambrian rocks, so the latter could occur throughout the drainage-basin area.

Subglacial conditions change from erosional to predominantly depositional closer to the grounding line. ROV dives on the north side of the MGT, along the last

Fig. 2. Images collected during ROV dives at and near the grounding line of Mackay Glacier. Relative scales are given in the description of each image because absolute scales were not determined for every image during ROV dives. Scenes $(a)-(e)$ depict the wide variety of conditions at the grounding line: (a) subglacial till with a very high angle of repose indicating a high degree of consolidation (clasts are large pebbles and cobbles) (note scalloped melt cusps on the ice surface); (b) subglacial till with a lesser degree of consolidation and a higher mud content than in (a) (clast in left foreground is a boulder); (c) fluted subglacial till coming out from under the grounding line which is floating on the right and grounded with a vertical cliff on the dark ridge in the left background (flutes are about $0.5 \mathrm{~m} \mathrm{high);} \mathrm{(d)} \mathrm{angular} \mathrm{clasts} \mathrm{of} \mathrm{rubble} \mathrm{at}$ the grounding line with a $6 \mathrm{~cm}$-diameter scallop in the foreground; and $(e)$ the glacier sole with scalloped melt-cusp surface directly in conlact with bedrock (scallop shells on bedrock to the left are $6 \mathrm{~cm}$ across). Images $(f)-(l)$ are from proglacial sub-glacier-tongue environments: $(f)$ shelftstone diamicton with boulders forming a local hardground; $(g)$ fluted till similar to that at the grounding line into which a boulder has been dropped from the base of the floating glacier tongue about $10 \mathrm{~m}$ above the sea floor; ( $h$ ) a crag-and-tail feature formed in the lee of a large boulder independent of flutes; (i) an irregular subglacial till surface probably produced by instant freezing of pore water in the till by pressure release as the tongue rapidly lifted from ils bed during a grounding-line retreat (relief on the sea floor is about $0.5 \mathrm{~m}) ;(j)$ a block of ice very rich with debris lying on the sea floor under the glacier tongue (the block is about $2 \mathrm{~m}$ long); ( $k$ ) a recently calved iceberg that has rotated such that its keel came down onto the sea floor in a rich epibenthic community - a large boulder with an attached sponge and feather star rests against the keel; and (l) a small push ridge about $0.5 \mathrm{~m}$ high, formed during a wallow by an iceberg. 







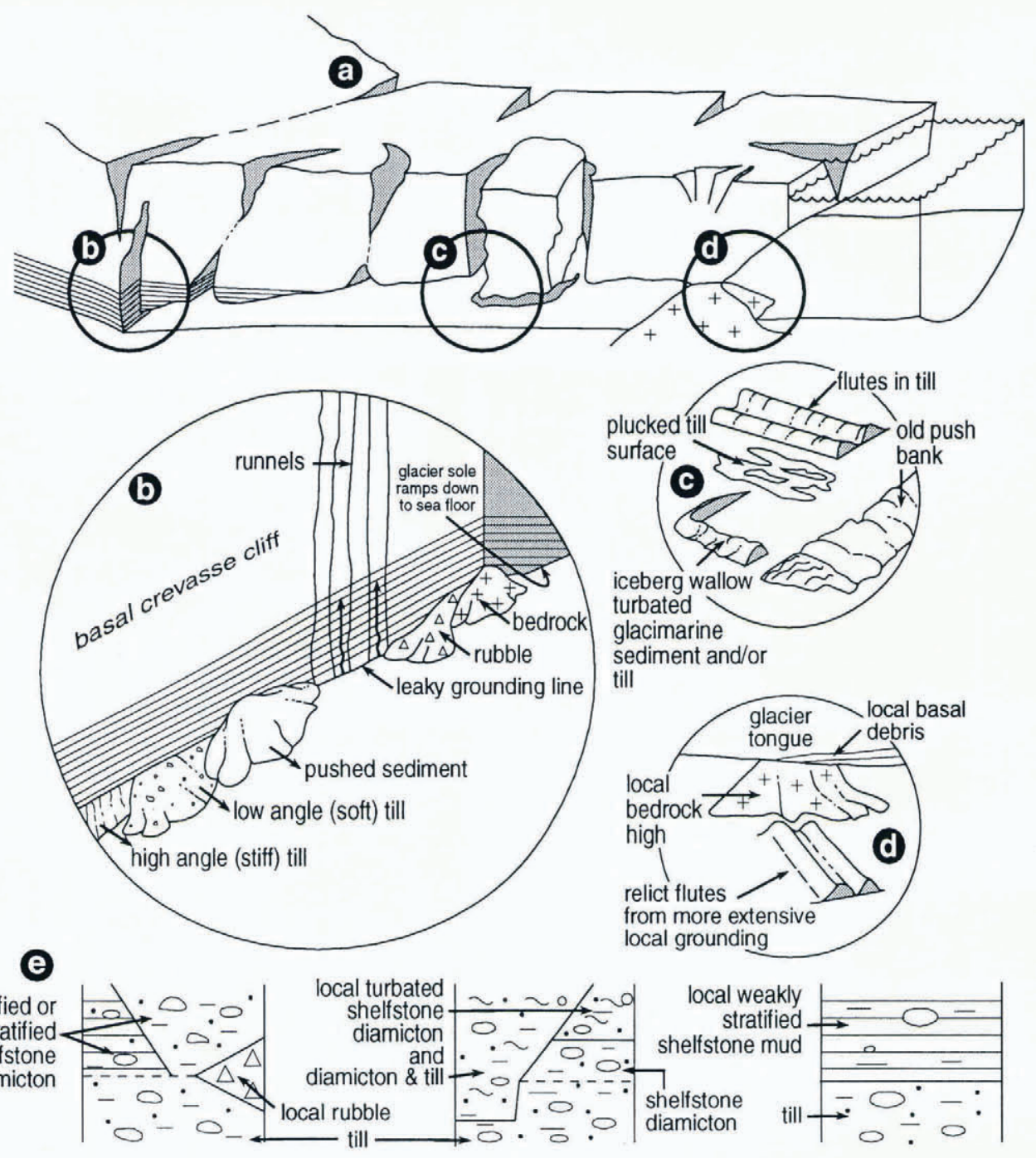

\begin{abstract}
Fig. 3. Conceptual model of important sedimentary processes and deposits of the Mackay Glacier Tongue. The general setting (a) shows basal debris being transported to the grounding line where the tongue has both a vertical wall of a basal crevasse and a slope down to the sea floor. Beyond the grounding line, basal debris is eventually melted out from the glacier, icebergs detach from the tongue to produce wallows or scours and there is a local pinning point on a bedrock high. Specific enlarged areas show major deposits and morphological features: (b) at the grounding line of a basal crevasse cliff, (c) on the sea floor beyond the grounding line, and (d) at the pinning point. Three idealized facies sequences (e) show the variability in facies that may be produced under different local conditions. All sketches are not to scale, for ease in depicting important features.
\end{abstract}

$1.8 \mathrm{~km}$ the glacier is grounded (Fig. 1, sites 1-4), show that basal debris thins from $20 \mathrm{~m}$ to $10 \mathrm{~m}$ thick, indicating subglacial melting and debris release which presumably results in deposition of subglacial till in this zone.

Clean white ice makes up the rest of the glacier above the basal debris layers, and the white ice is virtually free of debris. Englacial debris layers are found higher in the ice in icebergs, and were observed by profiling the ROV up the glacier face. These layers are rare and, having a similar appearance to basal debris, they appear to have been derived subglacially. The volume of debris the can contribute to the sea floor is relatively insignificant because they are only a few centimeters to $1 \mathrm{~m}$ thick when exposed in the icebergs.

\section{Grounding-line system}

The actual position of the grounding line has been located at several sites on the north side of the MGT in water depths of 100-140 m. However, no grounding line was found on the south side in similar water depths, even at two locations very close to bedrock valley sides at Cuff Cape (Fig. 1, sites 12 and 13). These ROV observations demonstrate that the grounding line does not run linearly across the fjord; it is tortuous and its form is a function of sea-floor topography. Commonly, the glacier has subglacial crevasses at the grounding line where flexure of the glacier tongue due to tides and swells is accommodated. By accommodating flexure of the tongue, bottom crevasses appear to reduce tidal pumping in the area of the grounding line because the sea floor is not eroded from higher current velocities in the water column, as would be expected with pumping. There is no apparent grounding zone; that is, the glacier tongue does not rise and fall with short periodicity over wide areas such that the trace of its contact with the sea floor is a zone. The 
ROV survived being trapped between the sea floor and the sole of the tongue for $24 \mathrm{~h}$, showing no major vertical movement of the MGT around the grounding line. Other sections of the MGT sole slope to the sea floor, and if that condition were more common, tidal pumping might be more effective.

The nature of grounding-line sediment varies spatially (Fig. 1, sites 1-4) from stiff till with a steep foreslope, through apparently softer till that cannot support such a steep angle of repose, to even softer till with a fluted form. There can be a flat till-surface rubble, a clean contact directly on bedrock, or banks being pushed by the glacier (Figs $2 \mathrm{a}-\mathrm{e}$ and $3 \mathrm{~b}$ ). By having different angles of repose in exposures at the grounding line, subglacial till appears to vary in rheology over tens of meters spatially on account of containing different amounts of water and mud. If subglacial sediment is sufficiently fluid and deforming toward grounding lines, then sediment gravity flows are predicted to flow from them (Powell and Domack, 1995). However, neither such flows nor deposits of possible past flows were observed.

Texture of the subglacial till appears to vary with proximity to bedrock; the till has a higher proportion of angular clasts, reaching a texture of pure rubble, when bedrock is close to the glacier sole. This relationship appears to indicate that debris is being locally eroded subglacially, in what is generally an area of debris release and subglacial till deposition just behind the grounding line, as explained above.

Locally, till on the sea floor at the grounding line is fluted, and in one location the flutes were observed to be coming directly out from the grounding line at a vertical ice cliff (Figs 2c and 3c). Till in the flutes appears to be quite soft, since an ice-shelf-rafted boulder made a deep impression when it dropped onto a flute (Fig. $2 \mathrm{~g}$ ). The degree of subglacial till deformation reflected in flute formation could not be determined.

Where the base of the MGT slopes down to the grounding line the sea floor is flat, with boulders protruding from it. It consists of diamicton, which is interpreted as subglacial till, that is draped with glacimarine sediment. In areas where basal crevasses form a vertical face at the grounding line, bottom sediment is commonly pushed into ridges of bouldery diamicton draped with mud and dropstones, but locally in two small areas these morainal-bank ridges are made of stacked, open-framework boulders. Some banks have steep, angleof-repose slopes several meters high.

Bottom sediment making up the grounding-line system is predominantly diamicton with very little sorting, indicating that there is little free-flowing subglacial water. Furthermore, no fresh water was documented at the grounding line by the ROV whose conductivity/temperature (CTD) sensor can be maneuvered to within about $10 \mathrm{~cm}$ of the ice wall. No conduits, large or small, were observed, and a lack of fluvial deposits on the sea floor also indicates that channelized flow has rarely, if ever, been active at the grounding line. Any subglacial water must be contained within subglacial sediment, be lost through groundwater, or flow as a thin film between till and the glacier sole. The latter water film would escape as a thin sheet along a "leaky" grounding-line margin and flow as a thin boundary layer against the ice face beyond the grounding line. Such flows would not be able to transport significant sizes and volumes of sediment. Suspended-particulate-matter (SPM) concentrations were observed to increase near the grounding line and may have been diffused from such flows. However, as concluded below, they could also originate from increasing sea-water velocities near the grounding line.

Runnels melted up vertical sections of ice along tens of meters of the grounding line are thought to be evidence for a thin sheet of subglacial water escaping from a leaky grounding line (Fig. 3b). The runnels extend through the basal debris zone with wavelengths of $0.2 \mathrm{~m}$ and depths of $0.15 \mathrm{~m}$, and up into clear, white ice above which they have wavelengths of $0.5-0.6 \mathrm{~m}$ and depths of $0.3 \mathrm{~m}$ and are 2-3 $\mathrm{m}$ long (Powell and Domack, 1995). They are caused by water rising vertically up the ice face as a boundary layer in helicalflow vortices, as has been described at tide-water cliffs of temperate glaciers (Powell and Molnia, 1989). The source of vertically flowing water must be localized, since ice in other areas at the grounding line has the scalloped form of melt cusps common elsewhere over the submarine surface of the glacier tongue. A suggestion for the source of the water is a subglacial fresh-water film which can be added to by melting of the ice face during buoyant rising flow (cf. Greisman, 1979; Huppert and Josberger, 1980; Josberger and Martin, 1981). Another cause of runnels may be sea water being forced to well up as it encounters the grounding line at a vertical ice face. The sea-water flow could be enhanced by "tidal pumping" action where the floating tongue rises and falls with the tide, but that appears to be small at the MGT. Some weakly stratified shelftstone mud may form locally beyond the grounding line as velocity fluctuations in these discharges transport different particle sizes.

When the ROV scanning sonar showed it was within $10-20 \mathrm{~m}$ of the grounding line, increasing siliciclastic SPM almost always decreased visibility. Locally, distinctly stronger currents with high SPM concentrations flowing away from or parallel with the grounding line were observed visually as well as with an ROV current meter. The ROV CTD sensor shows that water in these flows is as saline and as cold as surrounding bottom water that has not mixed with glacial water. The enhanced currents probably originate from in-flowing sea water being forced into a smaller and smaller gap between the ice and the sea floor; by continuity, the water must flow faster. The consequence is faster melting and easier SPM entrainment by the water layer. These currents may sort sediment as it rains out from melting of basal debris, to produce areas of weakly stratified glacimarine sediment. Areas with subglacial crevasses should slow these currents by allowing the flow to expand, and may be sites of mud deposition. Some spatial variation in glacimarine sediment thickness and texture would be produced. Densities of epibenthic communities decrease toward the grounding line as a reflection of increased SPM, and the main forms are vagrant deposit feeders or are nektic Dawber and Powell, 1995). Antarctic scallops (A. colbecki) are also numerous at the grounding line in several places. 


\section{Sea floor beyond the grounding line}

Within $300 \mathrm{~m}$ of the present MGT grounding line, the sea floor appears to have been recently exposed by lifting off of the glacier and consequent retreat of the grounding line. Areas exposed most recently have the least glacimarine sediment drape, and the surface is on relict subglacial till that is often fluted and locally rough (Figs $2 \mathrm{i}$ and $3 \mathrm{c}$ ). Areas with rougher surfaces occur in patches on the till surface and are thought to result from plucking of the till as the glacier lifted from the surface during rapid retreat of the grounding line. As the glacier lifts from its bed, the decrease in pressure instantly freezes pore water in the subglacial till, which freezes to the sole of the glacier in a way similar to that when icebergs calve from temperate glaciers (Powell and Molnia, 1989; cf. Alley and MacAyeal, 1994). Whether the patchiness with which this process occurred was due to the amount of water in subglacial till or to processes during lift-off could not be determined.

Other geomorphic forms, interpreted as flutes, also have a subglacial origin, as observed at the grounding line, and were also probably exposed during groundingline retreat (Fig. 3c). They have the form of ridges that occur on two scales; the smaller has an amplitude of 0.2 $0.4 \mathrm{~m}$ and the larger $0.75-1.0 \mathrm{~m}$. Ridge axes are parallel to ice-flow direction. The ridges are formed in diamicton that has a texture similar to the basal debris and the grounding-line flutes described above. Within the flutes, crag-and-tail features are formed around boulders in the direction of glacier flow, and one crag-and-tail feature was observed at a large boulder independent of the flutes (Fig. 2h).

Overlying this recently exposed subglacial till is a sheet of soft glacimarine sediment extending away from the grounding line. This sediment drape is shelfstone sandy mud and shelfstone diamicton (as in Powell, 1984) having a poorly sorted texture similar to that of its basal debris source. The poor sorting of the drape indicates there is little subsequent sorting during rain-out after being released by undermelting of the MGT. This zone of shelfstone glacimarine sediment extends down-glacier to a distance where the basal debris source becomes exhausted. The drape is also locally patchy and muddier due to winnowing during the rain-out process by either the thin-sheet discharges of subglacial fresh water, or subglacier-tongue marine currents, or possibly redeposition by bottom currents.

Iceberg scours and wallows were commonly observed along the sides of the MGT during ROV investigations. A wallow (cf. Reimnitz and Kempema, 1982) is produced after an iceberg calves from the MGT and local water depth is too shallow for its keel. As an iceberg calves it rotates to its own new equilibrium position which may mean its keel rests on the sea floor. It then sits in place and rocks in currents producing depressions in the sea floor, ridges squeezed into bottom crevasses of the iceberg, and ridges pushed at the berg's edge (Figs $2 \mathrm{k}-1$ and $3 \mathrm{c}$ ). During one ROV dive, a small piece of brash ice, presumably a fragment from a calving event, was observed sitting on the sea floor because it had a very high concentration of debris (Fig. $2 \mathrm{j}$ ). If they are large enough and buried rapidly, such blocks could produce submarine kettle forms.

If icebergs are either pushed by the MGT or moved by wind, ocean currents or sea ice, then their keels are dragged through the sediment which they scour. The scours have vertical relief of up to $2 \mathrm{~m}$, width of up to $3 \mathrm{~m}$ and variable orientation with respect to the MGT. Iceberg keels can greatly disturb bottom sediment to modify it into what has been termed iceberg-keel turbate (Vorren and others, 1983; Dowdeswell and others, 1994). Scours are distinguished from flutes by having negative irregular relief rather than a positive, smoother, form, and by having a random rather than unimodal axial orientation parallel with ice flow.

Epibenthic communities are dramatically disturbed by iceberg-scouring, but although their diversities under the glacier tongue vary areally, they appear to be influenced mainly by distribution of SPM and areas of hardgrounds. The hardgrounds are primarily gravel of various sizes (large pebbles and boulders are 10-15\% of the floor) projecting above fine-grained sediment (Dawber and Powell, 1995).

A pinning point near the MGT terminus is formed where the tongue is aground on a bedrock ridge (Figs 1 and $3 \mathrm{~d}$ ) which probably controls, in part, the present length of the tongue. At the site, the surface of the tongue forms a rise, and the ice falls away from the high in a series of normal extensional faults. The glacier erodes bedrock, incorporates debris at its base, and deposits sediment at the local grounding line, as at the true grounding line. The epibenthic community in areas up to $250 \mathrm{~m}$ away from the pinning point becomes relatively sparse and less diverse and the sea floor is fluted (Fig. 3d), both of which indicate the MGT was more extensively grounded here in the recent past.

\section{CONCLUSION}

These results are summarized in a conceptual model of this fast flowing polar glacier ending in the sea as a floating terminus (Fig. 3). Subglacial till forms a sheet diamicton that can locally coarsen in texture near bedrock. The till may have a fluted surface and may be pushed into morainal banks at the grounding line or be scoured and turbated by icebergs after grounding-line retreat. Compositionally, the till is mainly derived from local bedrock sources and could potentially vary in degree of consolidation if the variability observed spatially with the ROV is maintained temporally. The subglacial till can also contain angular clasts from basal rather than supraglacial sources, and it contains few or no subglacial fluvial deposits. Local grounding zones at bedrock pinning points under the floating terminus produce subglacial and grounding-line deposits similar to those at a true grounding-line area.

Subglacial till is directly overlain by glacimarine sediment of shelftstone diamicton and shelfstone mud of the same composition and very similar texture to the till (Fig. 3e). In the stratigraphic record this transition may be difficult to detect because, depending on the local 
rheology of the till, glacimarine sediment may have a similar degree of consolidation. Glacimarine sediment accumulates to several hundred meters down-glacier from the grounding line, beyond which the source of sediment, basal debris, has been totally melted out from the floating glacier. This ice-shelf-zone sediment may occasionally become more extensive if the grounding line retreats rapidly by virtually instantaneous lift-off of the glacier sole from the subglacial till bed over wide areas. The liftoff process may locally produce irregular pits on the subglacial till surface due to a pressure-release mechanism freezing till to the glacier sole at the instant of lift-off. The glacimarine sediment may be turbated with till by icebergs in shallower water depths.

These results show very different sedimentary depositional systems than those at grounding lines of temperate glaciers which all end as tide-water cliffs. The major difference is a comparative lack of meltwater in this coldglacier setting. The model is much less complex in facies architecture than for temperate settings and is similar to that suggested by Hambrey and others (1991) from drill cores on the Antarctic continental margin. A modification from Hambrey and others' (1991) model is that the till can be pushed into the form of a morainal bank (cf. Powell, 1984), but it has very different lithofacies than those of temperate glacier banks which are made of sorted sediment or a mixture of sorted sediment and diamicton. Also, locally, rubble may be produced from nearby bedrock and the upper surface may be disturbed during grounding-line retreat by pressure-induced till freeze-on and iceberg turbation. The extent of bottom fauna in close proximity to the grounding line differs greatly from that in temperate glacimarine settings.

\section{ACKNOWLEDGEMENTS}

This research is funded by the Office of Polar Programs, U.S. National Science Foundation, grants DPP8822098 and OPP9219048. We thank the staffs of the United States Antarctic Program (USAP), Antarctic Support Associates (ASA), the New Zealand Antarctic Programme (NZAP) and U.S. Navy for their support of field operations, and Dr P. Barrett who was instrumental in facilitating the collaboration through NZAP for the first field season of this project. Field personnel who have provided valuable help in the project are $\mathrm{S}$. Bograd, E. Broughton, T. Hooyer, L. Hunter and J. McNamee. Drs J. Dowdeswell and D. Collins made helpful suggestions in reviewing a previous version of this paper.

\section{REFERENCES}

Alley, R. B. and D. R. MacAveal. 1994. Ice-rafted debris associated with binge/purge oscillations of the Laurentide ice sheet. Paleoceanography. $94), 503-511$.

Alley, R. B., D. D. Blankenship, S. T. Rooney and C. R. Bentley. 1989 Sedimentation beneath ice shelves - the view from Ice Stream B. Mar. Geol., $852 / 4), 101-120$

Anderson, J. B. and L. R. Bartek. 1992. Cenozoic glacial history of the Ross Sea revealed by intermediate resolution seismic reflection data combined with drill site information. In Kennett. J. P. and D. A. Warnke, eds. The Antartic paleoemironment: a perspectize on global change. Parl 1. Washington, DC. American Geophysical Union, 231-263. (Antarctic Research Serics 56.

Calkin, P. E. 1974. Subglacial geomorphology surrounding the ice-free valleys of southern Victoria Land, Antarctica. 7. Glaciol., 13 69), $415-429$.

Dawber, M. and R. D. Powell. 1995. Study of the grounding-line sedimentation processes at the Mackay Glacier tongue using a remotely operated vehicle - observations on the sea floor epibenthic community. Antarct. F. U.S., 29 5 , 77 78.

Debenham, F. 1923. Report on the maps and surveys. British ("Terra . Noza") Antarctic Expedition 1910-1913. Vol. 1. London, Harrison \& Sons Ltd.

Dowdeswell, J.A., R.J. Whittington and P. Marienfeld. 1994. The origin of massive diamicton facies by iceberg rafting and scouring, Scoresby Sund, East Greenland. Sedimenlology, 41 1), 21-35.

Drewry, D.J. and A.P. R. Cooper. 1981. Processes and model of Antarctic glaciomarine sedimentation. Ann. Glaciol., 2, 117-122.

Engelhardt, H., N. Humphrey, B. Kamb and M. Fahnestock. 1990. Physical conditions at the base of a fast moving Antarctic ice stream. Science, 248 (4951), $57-59$.

Greisman, P. 1979. On upwelling driven by the melt of ice shelves and tidewater glaciers. Deep-Sea Res., 26 9A), 1051-1065.

Hambrey, M.J., W. U. Ehrmann and B. Larsen. 1991. Cenozoic glacial record of the Prydz Bay continental shelf, East Antarctica. In Mazzullo, E. K. and N.J. Stewart, eds. Proceedings of the Ocean Drilling Program. Vol. 119. Scientific results: herguelen Plateau Prydz Bay. College Station, TX, Texas A\&M University, 77-132.

Huppert, H. E. and E. G. Josberger. 1980. The melting of ice in cold stratified water. F. Phys. Oceanogr., 10 6), 953-960.

Josberger, E. G. and S. Martin. 1981. A laboratory and theoretical study of the boundary layer adjacent to a vertical melting ice wall in salt water. J. Fluid Mech., 111, $439-473$.

King, L. H., K. Rokoengen, G. B.J. Fader and T. Gunleiksrud. 1991. Till-tongue stratigraphy. Geol. Soc. Am. Bull., 103 5), 637-659.

Macpherson, A.J. 1987. The Mackay Glacier/Granite Harbour system (Ross Dependency, Antarctic) - a study in nearshore glacial marine sedimentation. Ph.D. thesis, Victoria University of Wellington.

Powell, R. D. 1984. Glacimarine processes and inductive lithofacies modelling of ice shelf and tidewater glacier sediments based on Quaternary examples. Mar. Geol., $57(1-4), 1-54$.

Powell, R. D. and E. Domack. 1995. Modern glaciomarine environments. In Menzies, J., ed. Modern glacial environments: processes, dynamics and sediments. Vol. 1. Oxford, Butterworth-Heinemann, 445-486.

Powell, R.D. and B.F. Molnia. 1989. Glacimarine sedimentary processes, facies and morphology of the south-southeast Alaska Shelf and fjords. Mar. Geol., 85 2-4), 359-390.

Reimnitz, E. and E. W. Kempema. 1982. Dynamic ice-wallow relief on northern Alaska's nearshore. J. Sediment. Petrol., 52 2), $451-461$.

Vorren, T. O.. M. Hald, M. Edvardsen and O. W. Lind-Hansen. 1983. Glacigenic sediments and sedimentary environments on continental shelves: general principles with a case study from the Norwegian Shelf. In Ehlers, J. ed. Glacial deposits in north-west Europe. Rotterdam, A. A. Balkema, 61-73. 